\title{
Still standing: Innocence work in England and Wales
}

\author{
Dr. Louise Hewitt \\ Director Innocence Project London, \\ Senior Lecturer University of Greenwich \\ Professor Claire McGourlay \\ Director Manchester Innocence Project, \\ University of Manchester
}

This article examines the two categories that have evolved in the literature concerning Innocence Projects; the pedagogical value of innocence work and the problems with associating the term innocence with the English criminal justice process. This research draws upon a study undertaken in 2017 by the Innocence Project London (unpublished) and another in 2020. Both studies sought to understand the extent to which organisations are undertaking innocence work in England and Wales. This research is written from the perspective of the Directors of both the Innocence Project London and Manchester Innocence Project, and as a result, the projects are discussed at length in various sections. An effort has been made however, to discuss other organisations that undertake similar work in various parts of this article.

I. Introduction

II. Method

III. Running an Innocence organisation in England and Wales

IV. The Innocence Project London

V. Manchester Innocence Project

VI. Innocence work and its pedagogical value

VII. Associating the term 'innocence' with the English criminal justice process

VIII. Conclusion

\section{Introduction}

The concept of innocence work in England and Wales was formally introduced in 2004 when it was explored in the context of establishing innocence projects in UK universities. This was when the Innocence Network UK (INUK) was set up to "facilitate academic study of wrongful convictions and miscarriages of justice, providing identifiable, accessible expertise, and a repository of evidence-based research to exploit in efforts to influence criminal justice system reform and government policy". ${ }^{1}$ The INUK, acting as an umbrella organisation encouraged the

\footnotetext{
${ }^{1}$ Michael Naughton \& Carole McCartney, Legal Ethics "The Innocence Network UK The Innocence Network UK" (2004) 7:2 Legal Ethics 150, online:

<https://www.tandfonline.com/doi/abs/10.1080/1460728X.2004.11424206>
} 
establishment of innocence projects at universities in the UK to "formalise, and augment ad hoc investigations undertaken by students in academic settings, and other individuals (i.e. investigative journalists, pressure groups)". ${ }^{2}$ The main two objectives of the Network were to assist convicted individuals who have exhausted the appeals process whilst at the same time providing accessible clinical legal education that touches upon all aspects of the criminal justice process. The INUK operated until July 2015 having successfully supported the development of over 30 innocence projects around the country. This success was also cited as one of the reasons it ceased operating. The former INUK website identifies the reasons for its cessation as: the failure of some projects to work to the relevant protocols; the disproportionate amount of time spent supporting innocence projects; and the need to work on the quality of assistance provided to wrongfully convicted individuals, in particular reducing the number of students who used the innocence project as a CV collector's item. From experience as Directors of the Innocence Project London and Manchester Innocence Project, we know these are issues still relevant today, and that they contribute to why the number of innocence projects has reduced drastically from 35 in 2015 to 23 in 2017 and now 12 in 2020.

This article examines the pedagogical value of innocence work, offering potential explanations for the significant reduction in the number of organisations working in the country. It also considers the issues raised in associating the term innocence with the English criminal justice process. The contents draw upon research undertaken in 2017 and 2020 by the Innocence Project London (unpublished), which sought to understand the extent to which organisations are undertaking innocence work England and Wales. Written from the perspective of the Director of the Innocence Project London, and the Director of the Manchester Innocence Project, this article draws upon their experiences running both organisations.

\section{Method}

It is a reality that the number of innocence organisations in England and Wales has dramatically reduced, but little research has been carried out on just how many are still operating. In 2017, the Director of the Innocence Project London, Dr Louise Hewitt developed and circulated a questionnaire to the innocence organisations that attended the Cardiff Innocence Ten conference in April 2016. Seeing as these were the last known innocence organisations to be active, this seemed like a good starting point. Most of the organisations were predominantly based in universities supported by academics although some were described as "student-led criminal appeal projects"; 3 however, one was an independent charity not based in a higher education setting. The questionnaire comprised of ten questions split into two parts. Part one is relevant to this article in that the questions sought to determine the background and structure of organisations undertaking innocence work:

1. Are you still operating a criminal appeals project, and if so what do you call it?

2. Is the project entirely student led or supported by an academic?

\footnotetext{
${ }^{2}$ Naughton and McCartney, supra note 1

${ }^{3}$ Holly Greenwood \& Dennis Eady, "Re-Evaluating Post-Conviction Disclosure: A Case for 'Better Late than Never'" (2019) 59 Int'1 JL Crime \& Just, online: https://doi.org/10.1016/j.illcj.2019.05.001>
} 
3. How many students and staff are currently involved?

4. How many cases are you working on?

5. How do you source your cases?

6. Is it a pro bono/extra-curricular project or an assessed module?

7. Is the project supported in any way by practising solicitors or barristers - if yes, could you please briefly outline how this works?

In 2020, Dr Louise Hewitt repeated the questionnaire sending it to the organisations that had responded positively to being active in the 2017 study using the same two-part template. Part one repeated questions one to five and question seven, but varied question six as follows:

(a) Is it a pro bono/extra-curricular project or an assessed module?

(b) What training/information is provided to the students to inform them of what the work entails?

(c) Does your project allow students to correspond directly with the client, and if so to what extent, e.g., letter/phone call correspondence/visiting client (please specify which)?

The results from both questionnaires are discussed in this article.

The obvious limitation to the questionnaires concerns additional information which would have been useful to know in the context of considering why innocence organisations were not still operating. For the purpose of both questionnaires, "entirely student-led" was taken to mean the work was carried out in the absence of an academic, whilst "supported by an academic" means the work was overseen and supported in this way. Another question could have asked how many organisations have made submissions to the CCRC and with what result. These questions were not included in the 2020 questionnaire, because the results of the 2017 questionnaire made it clear that the organisations undertaking innocence work were rapidly reducing. There was a danger that such work was becoming less significant and may disappear, therefore the necessity was to identify organisations that were still running and to see whether there was an opportunity to develop a more cohesive innocence work environment.

\section{Running an innocence organisation in England and Wales}

In England and Wales, if you plead not guilty to a serious criminal charge your case is heard in front of a jury at a Crown Court. ${ }^{4}$ If an individual is convicted at Crown Court, they have 28 days to appeal their conviction, requesting leave to appeal initially, and if granted this is followed by a hearing in the Court of Appeal. ${ }^{5}$ Individuals must demonstrate a serious error in law or procedure or some fresh evidence which has the potential to render their conviction "unsafe."

\footnotetext{
${ }^{4}$ Courts and Tribunals Judiciary, "What is the Crown Court", online: <https://www.judiciary.uk/you-andthe-judiciary/going-to-court/crown-court/>.

${ }^{5}$ Part 36 Criminal Procedure Rules and Practice Directions (2020), online:

$\langle$ https://www.gov.uk/guidance/rules-and-practice-directions-2020〉.

${ }^{6}$ Criminal Appeal Act, 1995 (UK), s 2(1)(a), online: 〈https://www.legislation.gov.uk/ukpga/1995/35>.
} 
If leave to appeal is denied or a full appeal dismissed, the only option for individuals maintaining their innocence to get their case back to the Court of Appeal is to make an application to the Criminal Cases Review Commission (CCRC). It is at this point that the work of the majority of innocence organisations in England and Wales starts. ${ }^{7}$ Whilst an application to the CCRC is free, the experience of the authors is that without assistance, convicted individuals struggle to articulate with clarity what amounts to fresh evidence or a new legal argument. Applicants to the Innocence Project London (IPL) that have already made an application to the CCRC have often not demonstrated fresh evidence or a new legal argument but have reiterated the case put forward by their defence team at trial. Research has supported this, suggesting that where individuals had legal representation or assistance they had "a significantly better chance" of their case being referred by the CCRC back to the Court of Appeal. ${ }^{8}$

The CCRC is an independent body which reviews possible miscarriages of justice in the United Kingdom, with the ability to decide whether a conviction or sentence should be referred back to the Court of Appeal. The CCRC conducts the "real possibility" test identified in s.13 of the Criminal Appeal Act 1995:

13. (1) A reference of a conviction ... shall not be made under any of sections 9 to $12 \mathrm{~B}$ unless-

(a) the Commission consider that there is a real possibility that the conviction ... would not be upheld were the reference to be made,

(b) the Commission so consider- (i) in the case of a conviction ... because of an argument ... not raised in the proceedings which led to it or on any appeal or application for leave to appeal against it...

This emphasis on "real possibility" in the statutory test has led to criticism that the CCRC has to second guess what decision the Court of Appeal will make. ${ }^{9}$ The Court of Appeal has made it clear that it does not have the advantage of the jury in hearing all the evidence, and that the assessment they need to make is whether the fresh evidence they have heard, if given at trial, might reasonably have affected the decision of the jury to convict. ${ }^{10}$ On this basis, the Court of Appeal has been accused of becoming increasingly resistant to legal challenges. ${ }^{11}$ The difficulty in defining "real possibility" has not helped provide a tangible threshold for applicants to meet:

\footnotetext{
${ }^{7}$ The Cardiff Innocence Project also provides assistance to individuals who are making a first appeal or out of time appeal.

${ }^{8}$ Jacqueline Hodgson \& Juliet Horne, "The extent and impact of legal representation on applications to the Criminal Cases Review Commission (CCRC)" (2009) SSRN, online:

<http://doi.org/10.2139/ssrn.1483721>.

${ }^{9}$ Michael Naughton \& Gabe Tan, "The right to access DNA testing by alleged innocent victims of wrongful convictions in the United Kingdom (2010) 14:4 Int'l J Evidence \& Proof 326, online:

$<$ http://www.innocencenetwork.org.uk/wp-content/uploads/2011/11/Naughton-and-Tan-IJEP-Nov2010.pdf>.

${ }^{10} R v$ Pendleton, [2001] UKHL 66, [2002] 1 All ER 524 (on appeal from the Court of Appeal).

${ }^{11}$ Sir Anthony Hooper, who retired in 2012 after eight years on the court of appeal, told a Panorama documentary aired in June 2018 see Matrix Chambers, A Change in approach from the CCRC online:

https://www.matrixlaw.co.uk/resource/a-change-in-approach-from-the-ccrc-by-anita-davies/
} 
The 'real possibility' test prescribed in section 13(1)(a) of the 1995 Act as the threshold which the Commission must judge to be crossed before a conviction may be referred to the Court of Appeal is imprecise but plainly denotes a contingency which, in the Commission's judgment, is more than an outside chance or a bare possibility, but which may be less than a probability or a likelihood or a racing certainty. ${ }^{12}$

Not having a definitive explanation of what amounts to a real possibility is to enable the CCRC to apply the test on a case-by-case basis, however the exercise of the its judgment has been said to be overly cautious. The Westminster Commission on Miscarriages of Justice report in March $2021^{13}$ said that the test put the CCRC in a position to be too deferential to the Court of Appeal, thereby limiting its ability to reach an independent judgment. It recommended developing a different test. A similar recommendation was made in 2015 by the Justice Select Committee. ${ }^{14}$ There have been no changes made to the test yet. Students working in an innocence organisation learn about these issues first-hand and develop a critical perspective on the effect the test has on their work when they are putting together an application for their client.

Learning and teaching in an innocence organisation is derived from clinical legal education where students work in small groups to review and investigate cases of convicted individuals who have maintained their innocence but have exhausted the criminal appeals process. Rather than being taught in a passive style through a dissemination of information from the lecturer to the student, learning is a result of direct involvement with the case. The cases place emphasis on the importance of facts, and of being sceptical and detailed throughout. ${ }^{15}$ Working at the end of the criminal justice process means that students deconstruct criminal cases, through an extensive investigation of fact alongside research into substantive law, to understand how and why their client was convicted. Students review all of the evidence and documentation available to them in an attempt to identify new evidence or a new legal argument that was not put forward at the initial trial or appeal stage. Each case is unique as to the substantive and sometimes procedural law students have to research and learn, and the legal issues which will often go beyond the law undergraduate curriculum. ${ }^{16}$ For example, students may have to consider a number of issues that go beyond the offence for which their client had been convicted, ranging from reviewing medical evidence concerning the injuries of the victim and the medical history of the client to considering expert evidence which means researching how an expert is defined by the law and the parameters in which they can give evidence.

\footnotetext{
${ }^{12} R$ v Criminal Cases Review Commission, ex parte Pearson, [1999] 3 All ER 498, [2000] 1 Cr App R 141 at $149 \mathrm{~F}-150 \mathrm{~A}$.

13 "Westminster Commission on Miscarriages of Justice report" (8 March 2021), online:

<https://www.gcnchambers.co.uk/westminster-commission-on-miscarriages-of-justice-reportpublication/>.

${ }^{14}$ Justice Committee, Criminal Cases Review Commission (Twelfth Report, Session 2013-14, HC 850) at para 20.

${ }^{15}$ Keith A Findley, “The Pedagogy of Innocence: Reflections on the Role of Innocence Projects in Clinical Legal Education” (2006) 13:1 Clinical L Rev 1111 [Findley].

${ }^{16}$ Daniel S Medwed, "Actual Innocents: Considerations in Selecting Cases for a New Innocence Project" (2003) 81 Neb L Rev 1097 [Medwed], online: 〈https://core.ac.uk/download/pdf/188093935.pdf>.
} 


\section{The Innocence Project London}

The IPL is based in the School of Law and Criminology at the University of Greenwich, a post-92 teaching focussed institution with a department of approximately 400 undergraduate law students. The name innocence project is trade-marked ${ }^{17}$ and therefore is limited to use by those who are members of the Innocence Network or who have been granted a licence to use the name by the Network. The Innocence Project London was the first English organisation to join the USA based Innocence Network in 2016, the Cardiff Law School Innocence Project uses the name under licence from the Innocence Network and the Manchester Innocence Project became the second English organisation to join Innocence Network in late 2020.

As an innocence project, the IPL accepts applications from individuals who have exhausted the appeals process, although it receives a number of applications from individuals who have yet to appeal, often facing appeals out of time. Unlike some innocence organisations run by practising lawyers, ${ }^{18}$ the IPL it is not set up to work on live cases that produce appeals (to the Court of Appeal). $R$ v Conaghan ${ }^{19}$ is a cautionary reminder for students and supervisors alike when assisting live cases, not only to the timeliness of making appeals, a point reiterated by the court as a clear and established principle, but also to compliance with the relevant procedures particularly where there is criticism of trial counsel. ${ }^{20}$ That said, the Cardiff Innocence Project, with the support of lawyers, has been successful in contributing to two appeals against conviction where one conviction was quashed, ${ }^{21}$ in addition to three referrals from the CCRC to the Court of Appeal, where one conviction was quashed. ${ }^{22}$

The work starts by ensuring each IPL applicants case is properly assessed to determine the possibility of making an application to the CCRC. Case assessments are carried out pro bono by lawyers working for London based law firm Weil and Gotshal. Using a case assessment template, groups of lawyers consider applications seeking to identify the possibility of a new legal argument or fresh evidence, in line with the requirements of the CCRC. The documents used for this process are normally the trial Judge's summing-up, grounds of appeal and any decision of the Court of Appeal or single judge depending on whether leave to appeal was allowed or denied. Sometimes applicants are able to provide other documents, such as witness statements or jury bundles.

The IPL does not request all their documentation at the assessment stage on the basis that not every case will be deemed eligible. Documentation for clients maintaining their innocence can best be described as their currency, especially the Judges summing-up from the trial. Moving between prisons and sending documents to various organisations to seek assistance means that case files can and do get lost. Innocence organisations often investigate cases that have incomplete paperwork which requires time to contact previous lawyers and/or organisations that have supported the individual to see if they have originals or copies of files. Losing case files can be

\footnotetext{
${ }^{17}$ Innocence Project ${ }^{\circledR}$ is the registered trademark of Innocence Project Inc. and is used under licence.

18 The Cardiff Innocence Project are able to accept appeal cases.

${ }^{19}$ [2017] EWCA Crim 597, [2017] 2 Cr App R 19.

${ }^{20} R$ v McCook, [2014] EWCA Crim 734, [2016] 2 Cr App R 30.

${ }^{21} R$ v Jones, [2018] EWCA Crim 2816, [2019] WLR(D) 16.

${ }^{22} R$ v George, [2014] EWCA Crim 2507, [2015] 1 Cr App R 15.
} 
costly, for example replacing a copy of the Judges summing-up requires paying a transcription service, and many applicants do not have the funds to do so. Therefore, full case files are only requested once a case is deemed eligible and accepted. The documents are reviewed and further questions asked of the applicant to determine whether there is the possibility of a new legal argument or fresh evidence. The reason for this is: firstly, so that the applicant is not given false hope that an application to the CCRC will definitely be made on their behalf by the IPL. All applications made to the CCRC by the IPL are done so by consent, in terms of the client agreeing the contents of the application. Lawyers who work pro bono with the IPL alongside the students, provide guidance on aspects of the application, but the IPL does not provide legal advice per se. Secondly, the students need to have something tangible to work on. The IPL operates mainly during term time, so as to ensure that most work can be carried out during that time, the case assessment process identifies the likely areas of investigation. The students themselves will deconstruct the case to find gaps in the evidence that led to the conviction, and thus they will determine the content of each area of investigation.

\section{Manchester Innocence Project}

The Manchester Innocence Project (MIP) operates under the umbrella of the University of Manchester Justice Hub. The university is research focused with a law department of approximately 1000 undergraduate students. In January 2016, the then School of Law commissioned an external review of clinical legal education provision and, following the provision of the external reviewer's report in $2016^{23}$ it was decided by the Head of School, Toby Seddon, that clinical legal education would become a core integral part of the Law School. Claire McGourlay was recruited as a Professor in Legal Education in 2017 to lead this process and to embed clinical legal education into the curriculum and to set up the MIP. ${ }^{24}$ The Justice Hub was created in 2017 and since then, two members of staff have been recruited to take on clinical legal educational teaching roles and to complement the existing team of two clinical leads and three professional services staff. Together the team at Manchester have worked towards both expanding and increasing the quality of the clinical legal education work and embedding this work into the curriculum and expanding what we do. The Justice Hub now provides a wide range of free legal services to the public and the Hub team works collaboratively with students and lawyers locally, nationally, and globally. It systemizes a diverse variety of components including the Legal Advice Centre; Manchester Free Legal Help; Dementia Law Clinic; Legal Tech and Access to Justice; Student Pro Bono Society; an International Project on Human Rights and a Vacation Scheme and of course, the MIP. The work of the MIP mostly mirrors the process of the IPL, and only accepts applications from individuals who have exhausted the appeals process. The main difference with the IPL is that the MIP has criminal lawyers working specifically for it and occasionally barristers help students with cases. The MIP also has at any one time, one or two post graduate research

\footnotetext{
${ }^{23}$ Vicky Kemp, Tine Munk \& Suzanne Gower, "Clinical Legal Education and Experiential Learning: Looking to the Future" (2016) U Man Sch L, online:

$<$ https://hummedia.manchester.ac.uk/schools/law/main/news/Clinical-Legal-Education-FinalReport28.09.2016.pdf>.

${ }^{24}$ Prior to this Professor McGourlay set up and ran the Sheffield Innocence Project, which later became the Miscarriages of Justice Review Centre when INUK disbanded.
} 
students working on cases, where these students are carrying out research into miscarriages of justice.

\section{Innocence work and its Pedagogical Value}

The value derived from students working in an innocence organisation in England and Wales has been misjudged and misunderstood, predominantly because of the distinct innocence project model of learning initially developed in the United States of America (USA). ${ }^{25}$ The assumption was made as far back as $2007^{26}$ that the discourse of innocence used in the USA would be imported into the English criminal justice system by innocence organisations operating in this country. However, this has not been the case. Both authors agree, from their own experiences of setting up and running innocence organisations it is not possible to take the innocence model in its American form and simply start using it with the English legal system because it is not a neat fit. The model, whilst a good template for student engagement and enquiry, requires modification in order to not only fit within higher education in England and Wales but also to fit with the requirements of the CCRC.

There are some distinct differences in how innocence organisations work in both countries. For example, student caseworkers on the IPL and MIP are predominantly undergraduate students, with only one or two postgraduate students. The majority of Innocence Projects in the USA work with students who are at Law School and are closer to becoming qualified lawyers. These students investigate the cases by talking to witnesses, finding evidence and arranging for the testing of that evidence if required. In England and Wales, undergraduate students require more supervision from the lead academic. Students do not interview witnesses, to avoid any issues surrounding contaminating evidence. ${ }^{27}$ Students identify evidence that they find missing from the case file for example CCTV, or rulings from the trial. They only attempt to recover that evidence however, under supervision from the lead academic, and with support from the lawyer working pro bono alongside them. Innocence Projects in the USA are able to litigate directly for their clients, where faculty members are qualified lawyers. For students in Innocence Projects in the USA, litigation involves mostly motions and briefs which they are encouraged to take ownership of. ${ }^{28}$ In contrast, innocence work in England and Wales does not involve students litigating for their clients. The focus is to make an application to the CCRC, which is the start of a "rule governed process" 29 where our innocence organisation needs to ensure that the evidence is new and significant and can satisfy the real possibility test. ${ }^{30}$

\footnotetext{
${ }^{25}$ Findley, supra at note 15.

${ }^{26}$ Hannah Quirk, (2007) "Identifying miscarriages of justice: why innocence in the UK is not the answer" (2007) 70:5 Mod L Rev 759 at 762 [Quirk 1].

${ }^{27}$ Kevin McMahon, founder of Merseyside Against Injustice, was convicted of perverting the course of justice for attempting to convince a prosecution witness to make a retraction statement shortly before the appeal hearing ('Former detective escapes prison' Daily Post 23 June 2004) online: https://www.dailypost.co.uk/news/local-news/witness-was-pressurised-2928068

${ }^{28}$ Findley, supra at note 15.

${ }^{29}$ Jon Robins, "What makes a strong application to the CCRC?" (2013) The Justice Gap.

${ }^{30}$ Ibid.
} 
The pedagogical value of innocence work has been globally recognised in existing literature. Jan Stiglitz, Justin Brooks and Tara Shulman ${ }^{31}$ identified innocence projects as providing practical legal education or put more simply, "learning through doing." Identifying the innocence model of clinical legal education, Stiglitz, Brooks and Shulman set out the value of this type of work in law schools. In 2003, Daniel Medwed ${ }^{32}$ drew attention to opportunities derived from the innocence model ranging from fact investigation, interviewing and creative problem solving in complex cases. Keith Findlay ${ }^{33}$ expanded on this, setting out a pedagogy of innocence which provides unique opportunities for learning that are derived from the work of innocence organisations. The hands-on experience of innocence work is discussed in detail by Stephanie Roberts and Lynne Weathered ${ }^{34}$ in the context of the benefit that thus type of clinical legal education provides. Students acquire not only new skills but the ability to think critically about the criminal justice system and how it operates. ${ }^{35}$ Carole McCartney goes further and highlights the effect of innocence work on the lawyers of tomorrow, how it helps them to develop their ethics and responsibility for their practice, in addition to a lifetime commitment to pro bono work. ${ }^{36}$ This has been expanded to transferrable skills such as time management, team working, written and oral presentation skills and problem solving. ${ }^{37}$ Louise Hewitt recently sought to evidence the impact of innocence work by drawing together a collection of students stories about their experience of working on the IPL. ${ }^{38}$ The collection used a model of autobiography to encourage students to reflect on their learning and tell their very personal stories about the effect of innocence work on their lives. ${ }^{39}$

The pedagogy used by the Innocence Project London evolved over time, combining experiential learning and elements of work-based learning (WBL) to produce a positive

\footnotetext{
${ }^{31}$ Jan Stiglitz, Justin Brooks \& Tara Shulman, "The Hurricane Meets the Paper Chase: Innocence Projects New Emerging Role in Clinical Legal Education" (2002) 38:2 Cal WL Rev, online:

<https://scholarlycommons.law.cwsl.edu/cwlr/vol38/iss2/5/?utm source=scholarlycommons.law.cwsl.ed u\%2Fcwlr\%2Fvol38\%2Fiss2\%2F5\&utm_medium=PDF\&utm_campaign=PDFCoverPages $>$.

${ }^{32}$ Medwed, supra at note 16.

${ }^{33}$ Keith Findley, "The Pedagogy of Innocence: Reflection on the Role of Innocence Projects in Clinical Legal Education New York Law School Clinical Research Institute" (2006) 13:1 Clinical L Rev, online: 〈https://media.law.wisc.edu/m/jytyw/pegagogy-of-innocence_final_proofs.pdf $>$.

34 Stephanie Roberts \& Lynne Weathered "Assisting the factually innocent: the contradictions and computability of innocence projects and the Criminal Cases Review Commission" (2009) 29:1 Oxford J Leg Stud 43 [Weathered].

${ }^{35}$ Ibid.

${ }^{36}$ Carole McCartney, "Liberating Legal Education? Innocence Projects in the US and Australia" (2006) 3 Web J CLI.

${ }^{37}$ Michael Naughton \& Julie Price, "Innocence projects: a perfect solution for clinical legal education?" (2006) Directions: UK Centre for Legal Education at 13.

${ }^{38}$ Innocence Project London, "Autobiographical reflections of students undertaking innocence work" (2021), online under Resources: 〈https://www.iplondon.org>.

${ }^{39}$ It is available to view online: www.IPLondon.org
} 
employer/employee environment. ${ }^{40}$ The employer/employee relationship starts with the application process so students know the standard expected from those who work on the project. The two-stage process consists of a written report that requires independent research, with successful students invited for an interview, which helps filter out those students who only want to use the IPL as another activity to add to their CV. Beyond those skills already identified as being of value, significant learning opportunities on the IPL include visiting the client in prison and seeing the impact that being in custody can have. To then be able to interview the client and reflect on how their answers impacts their investigation into the case provides an experience that an undergraduate curriculum cannot give. Being able to encourage students to reflect on the skills and experience they have learnt supports the prospect of translating the learning into legal practice as well as other areas of work.

Maintaining the learning experience takes a lot of time, and is one of the reasons why the number of organisations undertaking innocence work in England and Wales has reduced over the past few years. In 2017, the 46 organisations that attended the Innocence Ten conference, (hosted by Cardiff Law School Innocence Project to mark its tenth anniversary) were contacted to see whether they were still actively undertaking any innocence/criminal appeals work. Only 23 organisations responded positively. The majority of the responding organisations were based in universities and were overseen by an academic. Only two organisations said they were predominantly student led taken to mean no support from an academic (see Part II - Method), which in the experience of the authors, indicates very limited oversight from an academic. This in turn can lead to ineffective case management, and a lack of understanding about to deconstruct a claim of innocence. Of the organisations based in universities, five operated on a pro bono basis using student volunteers, eight operated as part of an assessed module and also on a pro bono basis, and two operated solely as part of an assessed module.

In 2020, the 23 organisations that had told the IPL they were still active in 2017, were again contacted and sent the second questionnaire (see Part II - Method). A response was received from each one, but only 12 organisations were still active, 11 of which were university-based and one, a charity, operated outside of higher education. Out of these, nine organisations were managed/overseen by an academic, whilst the remaining three were student-led. This time the majority of the organisations were supported by practising lawyers that work pro bono alongside the organisation. Of the organisations that were based in universities, seven operated on a pro bono basis using student volunteers, two of the organisations ran as part of an assessed module, and two operated both as a module and on a pro bono basis.

Between 2017 and 2020, there has been a reduction of just under 50\% in organisations undertaking innocence work. Since 2015, when the INUK ceased to exist there has been a reduction of $66 \%$ in organisations undertaking innocence work. In this short space of time this is a significant number. Innocence work is time consuming. Research carried out by Holly Greenwood $^{41}$ highlighted the difficulty faced by academics finding sufficient time to manage

\footnotetext{
${ }^{40}$ Louise Hewitt, "Learning by Experience on the Innocence Project in London: The Employer/Employee Environment" (2018) 25:1 Int J Clin Leg Educ 73, DOI online: 〈https://doi.org/10.19164/ijcle.v25i1.697>.

${ }^{41}$ Holly Greenwood, "Rethinking Innocence Projects in England and Wales: Lessons for the future" (2021) How J Crim Justice 1 at 26 [Greenwood].
} 
running an innocence organisation alongside their lecturing responsibilities. ${ }^{42}$ The administration of the IPL takes a considerable amount of time each week with tasks that include but are not limited to: sending out new applicants packs, ${ }^{43}$ responding to new applicants alongside requesting the relevant documents for the case assessment process, managing the case assessment process including asking further questions of the applicant via letter, recruiting students through the twostage recruitment process, managing casework and students teams, responding to lawyers who want to work pro bono with the IPL, managing lawyers who work pro bono with the IPL, in addition to fund raising (the IPL became a registered charity in August 2020), and working with other organisations both for activism and changes in policy. Of course, some of these activities have processes already in place such as the application pack which has a GDPR compliant ${ }^{44}$ questionnaire, privacy policy and guidance document. ${ }^{45}$ Letters to applicants however are written on an individual basis depending on what they ask for and also what they send in, which can be time consuming. Similarly, administering the MIP is equally as time consuming and rigorous, mirroring the enormous effort put in by staff and students on the IPL. The only difference is that the MIP is not a registered charity but operates with charitable status within Manchester University. The MIP works closely with the external relations team in the School of Social Sciences to help promote its work and to carry out fund raising.

Responses to Greenwood's research suggests that academic leadership of innocence work was potentially problematic unless they had practiced criminal law. ${ }^{46}$ Hewitt's study revealed that in 2017 nine organisations said they did not have any support from a practising lawyer, whilst the remaining organisations utilised either qualified staff working in the university legal advice centre, or lawyers that were employed directly by the university. Greenwood's research suggested a lack of practitioner involved was because many lawyers were under the strain of their own workloads. ${ }^{47}$ However, the results from the 2020 questionnaire indicate that more lawyers were working with innocence organisations pro bono, which has been the experience of both the IPL and MIP.

The results from the 2020 questionnaire show that the majority of organisations operate using student volunteers, and only two operate on both a pro bono and assessed module basis compared to eight back in 2017. From the perspective of the IPL, engaging law students on a voluntary basis has been very successful. Both law and criminology students can apply to work on the IPL at the end of their first year of study. Both sets of students can volunteer on the IPL, but criminology students can apply to work on the IPL as a placement in their third year. The IPL stopped being offered to law students as a placement on an assessed module because it became evident that this attracted students who were not invested in innocence work but perceived it to be less work than a more traditional optional module. In addition, completing the assessment distracted the students from their work on a case, making it more of a means to an end, rather than students being invested in the outcome for their client. Offering the IPL as a placement to

\footnotetext{
${ }^{42}$ Greenwood above note 41 at $12-13$.

${ }^{43}$ See IPLondon.org: online: 〈https://www.iplondon.org>.

${ }^{44}$ General Data Protection Regulation 2016/679 online:

https://www.legislation.gov.uk/eur/2016/679/contents

${ }^{45}$ IPLondon, supra at note 42.

${ }^{46}$ Greenwood, supra note 41 at 13.

${ }^{47}$ Greenwood, supra note at 41.
} 
criminology students has had the opposite effect. Students are keen to learn aspects of the law and become invested in how they can improve the criminal justice system. Having limited knowledge of the law means they realise form the start that working on the IPL can be hard and that they are very unlikely to be able to get their client out of prison in the year of their placement, but they are already engaged in wanting to learn about how the criminal justice system works and how it can be improved from the moment they apply.

From the perspective of the MIP students are also engaged on a voluntary basis with equal success. The organisation receives around 150 applications each year from first and second-year students in the School of Social Sciences. ${ }^{48}$ The students who tend to apply are studying Law and Criminology. There is no linked assessed module, but Claire McGourlay runs a stand-alone optional assessed module focusing on Miscarriages of Justice for second and third-year undergraduate students which has an intake of approximately 200 each year.

\section{Associating the Term Innocence with the English Criminal Justice Process}

The work of innocence organisations has been defined by the use of the term innocence. Hannah Quirk in 2007 identified the necessity to progress the debate beyond the simplistic "dichotomy of guilt and innocence" 49 highlighting the difficulty with establishing clear-cut factual innocence. ${ }^{50}$ This issue however, stems more from the Court of Appeals difficulty in deciding appeals on factual grounds such as fresh evidence. ${ }^{51}$ The Court of Appeal does not declare people innocent on the basis that the Criminal Appeal Act 1995 gives the court the power to quash a conviction if it thinks it is "unsafe." 52 The Court of Appeals focus therefore, has been on procedural irregularity where it is noted they show too much deference to the decision of the jury, ${ }^{53}$ in addition to not wanting to risk opening the floodgates to a vast number of appeal applications. ${ }^{54}$ Roberts and Weathered have suggested that this means fresh evidence is often saved for an application to the CCRC placing innocence organisations in the best position to be able to assist clients who are claiming factual innocence. ${ }^{55}$ Innocence organisations do not, as has been suggested, usurp the role of the CCRC. ${ }^{56}$ Rather than trying to take the place of the CCRC, innocence organisations try

48 This includes Criminology, Politics, Economics, Sociology, Anthropology, Social Statistics and Law students.

${ }^{49}$ Quirk 1, supra note 26 at 762.

${ }^{50}$ Quirk, supra note 26 at 768.

${ }^{51}$ Weathered, supra at note 34.

${ }^{52}$ Criminal Appeals Act 1995 s 13.

53 Joshua Rozenberg, “Are too few convictions overturned?" BBC News (27 March 2015), online: 〈https://www.bbc.co.uk/news/uk-32053901>; see also Stephanie Roberts, "Fresh Evidence and Factual Innocence in the Criminal Division of the Court of Appeal" (2017) 81:4 J Crim L 30.

${ }^{54}$ Weathered, supra at note 34.

${ }^{55}$ Ibid.

${ }^{56}$ Hannah Quirk, "Uncovering disclosure errors: appeals, innocence projects and the Criminal Cases Review Commission" in Ed Johnson and Tom Smith (eds), "The Law of Disclosure: A Perennial Problem in Criminal Justice", Abington: Routledge, online: < https://ebin.pub/the-law-of-disclosure-a-perennialproblem-in-criminal-justice-2020037336-2020037337-9780367420147-9780367817411.html〉. 
to work with it, although there can be tensions in the relationship; both authors are part of the CCRC stakeholder group helping to support the CCRC in feeding back on systemic issues in the criminal justice system. ${ }^{57}$ Both authors have invited representatives from the CCRC to speak to students at their respective universities and also at seminars held to raise awareness of the work of innocence organisations.

Factual innocence was part of the INUK case selection criteria, ${ }^{58}$ which excluded individuals looking to overturn their conviction on grounds of procedural irregularities in the criminal justice process. Innocence organisations have moved on since the INUK with those still running suggesting they have broadened their focus. ${ }^{59}$ Both the IPL and MIP are members of the global Innocence Network, the mission statement of which is to provide, “...pro bono legal and investigative services to individuals seeking to prove innocence of crimes for which they have been convicted, working to redress the causes of wrongful convictions, and supporting the exonerated after they are freed." ${ }^{60}$ The IPL's guidance sets out three criteria for new applicants, the first of which is:

You must be claiming to be factually innocent of the crime you have been convicted of. We will only assist in cases where an individual is claiming to have absolutely no involvement in the crime at all, including claims that no crime has occurred at all (e.g. where deaths are accidental or resultant of natural causes as opposed to criminal homicides). ${ }^{61}$

Both the IPL and the MIP uses factual innocence in the context that the applicant must be maintaining their innocence. Fulfilling the eligibility criteria does not guarantee that the case will be accepted. During the eligibility assessment process, consideration is given to the merits of the case, overall strength of the evidence that led to the conviction, and whether there are viable lines of enquiry to investigate. We make it clear to applicants that cases are assessed to determine the prospect of new evidence or a new legal argument and that a decision of eligibility is not a judgment as to the validity of their claim of innocence.

The complexity of how factual innocence fits into the criminal justice process is evident in some of the existing literature. Tracing back the issues to the Court of Appeal demonstrates the difficulty in determining the relevance of factual innocence in the context of fresh evidence. Potentially the previous focus on factual innocence by the INUK may have led member innocence organisations to perceive that they no choice but to exclude cases based on procedural irregularities. However, the focus of the appeal process on an unsafe conviction forces innocence organisations and lawyers alike to find a route that the Court of Appeal will accept, and more often than not, that is new legal arguments in the form of procedural irregularities.

\footnotetext{
${ }^{57}$ Terms of reference

${ }^{58}$ Michael Naughton, "Confronting and uncomfortable truth: not all victims of alleged false accusations will be innocent" (2007) FACTion, November 8-12, online:

<https://www.fbga.redguitars.co.uk/michaelNaughtonNov07.pdf >.

${ }^{59}$ Greenwood, supra note 40 at 26.

${ }^{60}$ Innocence Network https://innocencenetwork.org/subcategory/our-work

${ }^{61}$ IPL guidance document available on IPLondon.org: online: 〈https://www.iplondon.org >
} 
Convicted individuals who apply to innocence organisations in England and Wales are often part of complex cases, which is why assessing them is so important to ascertain the potential to meet the criteria for the CCRC, which means looking for the potential for both fresh evidence and a new legal argument. Innocence has to be a feature of our work, not least because we support individuals who are claiming they did not commit the crime for which they have been convicted.

\section{Conclusion}

The deconstruction of a claim to innocence and the investigation of facts underpins the unique way in which students learn whilst undertaking this type of clinical legal education. It helps students acquire new skills and embed existing ones, but more importantly it enables them to develop a critical perspective of the criminal justice system in England and Wales. These students are future employees that will go on to work in the system and their commitment to improving it, and not repeating the mistakes of the past is vital.

Innocence work in England and Wales has been misunderstood, predominantly because the work has been defined merely by the use of the term innocence in our organisation's titles. The innocence project model from the USA has been adapted to work with the English legal system and the requirements of the CCRC, to the benefit of not only the clients who get support to access justice but also to the higher education establishments that support us through the provision of innovative learning through doing. One significant reason for the reduction in the number of innocence organisations is because maintaining this work is time consuming. As academics, we lecture and have other responsibilities within our respective departments. Delivering a clinical experience in innocence work on top of the day job is not easy but it is rewarding when students develop a commitment to pro bono activities that goes beyond their studies. The request for applicants to claim factual innocence does not preclude the possibility of a new legal argument, or does it mean we solely focus on finding fresh evidence. It is a selection criterion that manages the expectation of those who apply to our organisations for assistance, because we will only consider cases from convicted individual who claim to have no involvement in the crime for which they have been convicted. Our thorough and time- consuming investigations of fact will consider the possibility of both a new legal argument and fresh evidence, as we do not prioritise one over the other. Innocence organisations in England and Wales do not try to replace the CCRC, we provide support to the many individuals who want help making an application to them. The work of innocence organisations in England and Wales is a part of the criminal justice system, it may not be the same movement as our colleagues in the USA, but it should not be underestimated. 